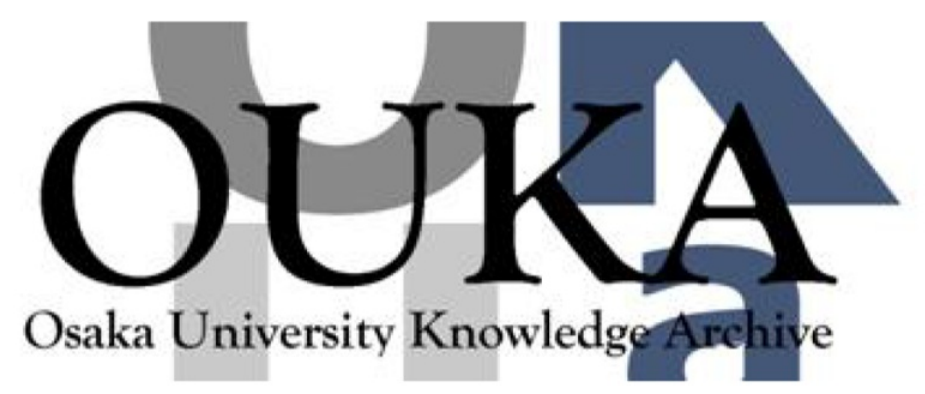

\begin{tabular}{|c|l|}
\hline Title & $\begin{array}{l}\text { SOME ASPECTS OF THE USE OF COMMERCIAL } \\
\text { ARBITRATION BY JAPANESE CORPORATIONS }\end{array}$ \\
\hline Author(s) & Nomura, Yoshiaki \\
\hline Citation & Osaka University Law Review. 33 p. 47-p. 64 \\
\hline Issue Date & $1986-03$ \\
\hline oaire:version VoR \\
\hline URL & https://hdl. handle. net/11094/6016 \\
\hline rights & \\
\hline Note & \\
\hline
\end{tabular}

Osaka University Knowledge Archive : OUKA

https://ir. Library. osaka-u. ac. jp/

Osaka University 


\title{
SOME ASPECTS OF THE USE OF COMMERCIAL ARBITRATION BY JAPANESE CORPORATIONS*
}

\author{
Yoshiaki Nomura ${ }^{\dagger}$
}

\section{INTRODUCTION}

Arbitration (chûsai) is one of the least popular methods for resolving disputes in Japan. ${ }^{1}$ It is much less popular than litigation (soshô), which itself is not often relied upon. ${ }^{2}$ The Japanese law of arbitration is found in Book VIII of the Code of Civil Procedure ("CCP"), which was patterned after the old German Code of Civil Procedure. ${ }^{3}$ It has been on the books for ninety-five years, but has seldom been relied upon.

Yet among Japanese businessmen doing business internationally, arbitration is quite well known; and it is a practice of many Japanese companies to insert in their international contracts an arbitration clause which provides for arbitration in Japan. ${ }^{4}$ International commercial arbitration has drawn constant attention from lawyers and scholars and it has been the subject of a large amount of legal writing. ${ }^{5}$

* This article is based on my paper submitted to Harvard Law School for the requirement of a research seminar supervised by Professor Oliver Oldman and Mr. James Feinerman for the academic year 1985.

+ Associate Professor of Law, Osaka University

1. See generally, Taniguchi, Dispute Settlement Framework, in 1 DoIng Business In JAPAN Ss. 12.03 (Z. Kitagawa, ed. 1980).

2. See generally, H.TANaka, The Japanes Legal System 254-68 (1976). In particular Tanaka points out, at 255, that the number of civil suits brought before the Japanese courts is far smaller than that of England, California or Massachusetts. Id. at 255-56.

3. Minji Soshôho, Law No.29 of 1890. English translation is found in Doing Business in JAPAN App. 6A (Z. Kitagawa ed. 1984).

4. For example, a "sales procedure agreement" between a Japanese manufacturer and a U.S. distributor provides, in pertinent part, "[a]11 disputes, controversies or differences which may arise between [Mitsubishi and Soler] out of or in relation to Articles I-B though V of [the sales procedure agreement] or for breach thereof, shall be finally settled by arbitration in Japan in accordance with the rules and regulations of the Japan Commercial Arbitration Association." Mitsubishi Motors Corporation v. Soler Chrysler-Plymouth, Inc., 723 F.2d 155, 157 (1st Cir. 1983).

5. See, e.g., Chûsai-kankei Sôgo Bunken Mokuroku (Bibliographies on Japanese Literature on Arbitration., 52 HôRıTsu JiHô, No.11 at 162-46. (1980); 53 HôRıTsu JiHô, No.2 at 154-74 (1981); 54 HôRıTsu JiHô, No.8 at 179-89 (1982). There are only a few articles written in English. A good description of commercial arbitration in Japan is found in Doi, National Report: Japan, IV YEARBook: COMMERCial Arbitration 115 (1979). For an introduction to an arbitration procedure, see Hattori, Arbitration, in 7 DoING Business IN JAPAN s.4.01 (1984). 
The recent ratio of arbitration/litigation for purely domestic cases is close to zero. ${ }^{6}$ With respect to international commercial disputes, however, more cases go to arbitration than litigation. ${ }^{7}$ What explains this difference in importance that arbitration enjoys in national and international contexts?

We will emphasize in this article aspects of the use of "commercial" arbitration by corporations since "international" cases most often take the form of commercial disputes between private corporations. ${ }^{8}$ We must however take into account some aspects of non-commercial arbitration and dispute processing. In sum, this article attempts to explain, in a broader framework of dispute resolution, the relative importance of arbitration for Japanese businesses to settle international commercial disputes as contrasted with the negligible role of arbitration in processing purely domestic disputes.

First, we look at the history of arbitration in Japan in order to show that arbitration was a product of legislation which was introduced in the process of modernization. Then we discuss some of the problems that the Japanese law of arbitration presents. The suggestion that the inadequacy of the law is one of the factors which discourages arbitration brings us to examine the practice of arbitration, with a special emphasis on Japanese arbitral institutions. Then we attempt to demonstrate that Japanese corporations' seemingly inconsistent approaches to arbitration for domestic and international settings are in fact based primarily on their dispute management strategies rather than by a vague idea that it is in the "national character" to love "harmony" (wa). However it is pointed out that their choice among alternative methods of dispute resolution is heavily influenced by the Japanese model of dispute settlement, "hanashi-ai" (amicable consultation), which is private and voluntary in creation, informal in procedure,

6. For example, in the $1975-80$ period, the number of civil suits handled by small claims courts and district courts all over Japan was 673,372 while the total number of arbitration cases recorded in the same period was only 118.

7. See infra note 53 and accompanying text.

8. The term "commercial" is used in this article to cover matters arising from all relationships of a commercial nature. It generally excludes such matters as consumer, labour, environmental or family law disputes. An arbitration is called "international" if the parties to an arbitration agreement have a different nationality (or a place of incorporation or principal place of business in a different state), or the subject-matter of the arbitration agreement is related to more than one state. In other cases where the parties and the subject-matter of agreement are related to only one state, i.e. Japan, that arbitration is called "purely domestic." Arbitration is domestic if the award is made within Japan, regardless of the parties" nationalities, or the subject-matter. For example, when arbitration is referred to a Japanese arbitration institution in Japan, by an American company against a Japanese company, it is domestic arbitration and also international arbitration. Domestic arbitration is contrasted with "foreign arbitration," which in most cases is covered by the 1958 New York Convention. See infra text accompanying notes 43-46. However when there is no danger of confusion, the word "domestic" is simply used to refer to a purely domestic or intranational situation. 
and non-legal in substantive standards to reach a settlement. The article concludes that the availability and normativeness of hanashi-ai coupled with some other factors determine whether arbitration is a reasonable alternative for Japanese corporations to utilize in a given dispute situation. Finally it will be suggested that a new legislation may be a plausible way to promote arbitration as an alternative dispute resolution for both domestic and international disputes.

\section{LAW OF ARBITRAtion}

Modern arbitration was introduced in Japan with the enactment of the Code of Civil Procedure in $1890.9^{9}$ Until then no comparable institution was known to the Japanese. ${ }^{10}$ People in Japan are still not accustomed to the concept of arbitration in the sense that parties agree to create a private court to settle their disputes and bind themselves by the resulting judgment. If the role of law concerning arbitration is to regulate as well as to assist arbitration, then there seemed to be no particular need for Japan to have a law of arbitration, since there was no arbitration to be assisted or regulated. In fact, the first tentative draft of the Code of Civil Procedure prepared by Techow, a German legal adviser, had no provisions for arbitration. ${ }^{11}$ The rules for arbitration were later added to this draft, which after several redraftings became the present $\mathrm{CCP}$. The added provisions for arbitration were a literal translation of Book X of the 1887 German Code of Civil Procedure, and they became Book VIII, entitled "Arbitration Procedure" (Arts. 786 to 805) of the Japanese CCP without substantial change. ${ }^{12}$ The CCP was amended several times, but Book VIII has undergone no substantial change since its enactment. ${ }^{13}$ There was no document to show why Techow did not include provisions for arbitration in his draft; neither was there any document to explain the later additions to his draft. It is interesting to note, however, that the Exchange Act of $1887,{ }^{14}$ which was superceded by the Exchange Act of $1893^{15}$ without going into force, had provisions for arbitration concerning "a dispute arising out of the transaction carried out at an exchange." 16 This may indicate that there were some people in the government who

9. See supra note 3 .

10. See N.Koyama, Chûsai Hô (Law of Arbitration) 18 (2d ed. 1983).

11. See Kikui, Meiji-ki Chûsai Kenkyâ (A Look at Arbitration in Meiji Era., 54 Hôrıtsu JıHô, No. 8 at $8-9(1982)$.

12. See ibid.

13. See, List of Amendments, in 1983 MoHaN Roppô (Selected Statutes. 1005-7. (1982).

14. Torihiki-jo Jôrei, Royal Decree No.1 of 1887.

15. Torihiki-jo Hô, Law No.5 of 1893. This law no longer had provision for arbitration.

16. See supra note 14 , Torihiki-jo Jôrei arts. 30-32. 
regarded arbitration as a useful means of settling disputes, at least with respect to stock or commodity exchanges. However, one can only guess whether or not the same people involved in the legislation of the 1887 Act moved to introduce arbitration in a more general way by incorporating the law of arbitration in the CCP.

It is more plausible to see the introduction of the system of arbitration as part of the whole endeavor on the part of the government to establish a modern legal system after the fashion of "developed" countries at the time. For one thing, sweeping legislation by way of codification was necessary to keep up with the rapid and great economic and social change that had taken place since the Restoration of 1868. But a more significant force which prompted the government to carry out quick and hasty codification was the desire to revise the unequal treaties which Japan had entered into with many Western countries. ${ }^{17}$. The remark made by Shimpei Eto, an early proponent of codification and then head of the Justice Department, well illustrates the situation:

If we are to achieve our purpose of revising the unequal treaties, there is nothing more urgent than vigorously codifying the law, however incompletely, establishing a judicial system, protecting civil and political rights, and thereby getting foreign nations to recognize that ours is a truly independent country. ${ }^{18}$

In fact, "developed countries" proposed, as a condition for giving up their extraterritorial jurisdiction in Japan, that she should present her completed codes to them for examination and approval. ${ }^{19}$

It was expected that codification would give Japan the apparatus of, or at least an appearance of, a modern state. As the whole project of codification was based on the general national policy for modernization, ${ }^{20}$ and not on specific policies to meet various social needs, the institutions to be established always ran the risk of being counter to traditional practice. Fearful of careless, incomplete codification, and of potential clashes between newly adopted rules and traditional values, many lawyers raised their voices against the Commercial Code and the Civil Code, which

17. See Hozumi, Lectures on the New Japanese Civil Code 10-11 (1912).

18. Y.MATONo, 2 Etô Nampaku 143, quoted in Kikui, supra note 11 at n.2.

19. See The Letter of July 29, 1887 from the Japanese Minister of Foreign Affairs to Foreign Ambassadors Extraordinary in 1 Jôyaku Kaisei Kankei Nıppón Gaikồ Bunsho, Kaigiroku 1188-89 (Ministry of Foreign Affairs Research Buraeu, et al. ed. 1948).

20. See, e.g., Gokajô no Goseimon (Imperial Oath of the Five Articles), quoted in Hozuml, supra note 13 at 3-5. It was declared in art. 4: uncivilized customs of former times shall be broken through and everything shall be based upon just and equitable principles of nature. Art. 5 stated; "Knowledge shall be sought for throughout the world, so that the welfare of the Empire may be promoted." 
would have gone into force in 1891 and 1893, respectively. ${ }^{21}$ The series of "Codification Controversies" (Hôten Ronso) between 1890 and 1892 ended in favor of the "Postponement Camp," which resulted in the new legislation of the Civil Code and the Commercial Code. ${ }^{22}$ Probably because of its rather technical nature, and probably because of its earlier promulgation, the CCP survived the "Codification Controversies." After the large scale revision in 1926, the CCP underwent several revisions all of which left Book VIII substantially untouched. ${ }^{23}$

If the only role of the law of arbitration is to regulate, and not assist arbitration processes, then the CCP has necessary mandatory provisions concerning such subjects as arbitrability (Art. 786), effect of awards (Art. 800), setting aside of awards (Art. 801), and enforcement of awards (Art. 802). ${ }^{24}$ As a result, it may not be necessary to revise the law where there are few cases of arbitration, and the need for arbitration is not strongly felt by the community.

On the other hand, if we look at the law of arbitration as a means to assist private dispute settlement, then it becomes obvious that the CCP lacks many provisions which concern some important subject matter. For example, separability of the arbitration clause and effect of the agreement as a demurrer are not provided for, though they are recognized by courts. ${ }^{25}$ The CCP is also silent on applicable substantive rules, interim measures of protection, correction and interpretation of awards, and publication of awards. ${ }^{26}$

Book VIII of the CCP contains no special provisions for international arbitration. The provisions of the CCP are applied territorially to arbitration in Japan whether it is an international case or a purely domestic one. ${ }^{27}$ Of particular importance in an international situation are the determination of rules of procedure for arbitration and that of applicable rules to the substance of a dispute. The CCP provides that in the absence of any agreement between the parties as to the arbitral

21. See generally, Takayanagi, A Century of Innovation: The Development of Japanese Law, 1868-1961 in Law in Japan 15-40 (von Mehren ed. 1963).

22. See ibid. See also Hozumi, supra note 17 at 14-24.

23. See, List of Amendments, supra note 13 at 1005-7.

24. See infra text accompanying notes $42-46$.

25. See Kokusan Kinzoku Kôgyô K.K. v. Guard-Life Corp., S.Ct. Judgment, July 15, 1975, 29 Minshû 1061. In Kokusan, there was a distributorship agreement between the plaintiff Japanese manufacturer and the defendant New York corporation, which contained a clause providing for arbitration in Tokyo under the Rules of the Japan Commercial Arbitration Association. The plaintiff brought an action for declaration that the distributorship agreement was not validly concluded and that therefore the arbitration clause contained therein was invalid. The Supreme Court held that unless there was a special agreement between the parties, a defect in the formation of the principal contract did not affect the validity of the arbitration agreement.

26. As for applicable rules to substance of dispute, see infra text accompanying notes 30-33.

27. See supra note 8 . for the definitions of international and purely domestic arbitration. 
procedure, this shall be determined by the arbitrators at their own discretion (Art. 794, para. 2). Therefore Art. 794 contemplates parties' freedom to lay down the rules of procedure. The party may agree to adopt the rules of arbitration which follows the law of a foreign country, ${ }^{28}$ unless the chosen procedure is contrary to public policy of Japan or some mandatory rules contained in the CCP. ${ }^{29}$

There is no rule in the CCP to determine which substantive law or rules the arbitral tribunal shall apply to decide a dispute. Although the parties' full autonomy to determine the issue is recognized by doctrine and practice, ${ }^{30}$ it is subject to public policy or mandatory rules of the CCP. ${ }^{31}$ In the absence of choice by the parties, arbitrators are not obliged to make their decision in accordance with rules of law. One court stated, in a purely domestic case, that arbitrators "may also render the decision ex aequo et bono (kôhei no kenchi yori) taking into consideration all the circumstances of the case." 32 The state of law concerning this issue is not yet clear. But we must note that the principle and practice with respect to a decision ex aequo et bono are now inconsistent with the majority view of international community as embodied in article 28 of the Draft Text of a Model Law on International Commercial Arbitration. ${ }^{33}$

One mandatory rule which has special implications for international trade is contained in Art. 786 concerning the validity of arbitration agreements. Art. 786 provides that an arbitration agreement is "valid only insofar as the parties are entitled to settle the matter in dispute." That is to say, if the parties are not entitled to settle an issue in dispute, that issue may not be arbitrable. Therefore, not only is such an issue as antitrust or bankruptcy not arbitrable, but if the dispute gives rise to a foreign antitrust or bankruptcy issue, that issue may not be arbitrable in Japan. ${ }^{34}$

Other mandatory rules for arbitration are embodied in the provisions of the

28. See The Oriental Hotel, Ltd. v. A.D. Larande, Osaka App. Ct., July 24, 1917, Hôritu Shinbun, No. 1298 at 31 .

29. If one of the parties was denied due process by the chosen procedure, the resulting award is subject to challenge or denied enforcement. See CCP art. 801 para. 1 (1) \& (3); art. 802 para 2. See also infra text accompanying notes $43-46$.

30. See, e.g., Koyama, supra note 10 at 178.

31. If a foreign law chosen by the parties permitted them to settle an issue which is not arbitrable under the law of Japan, the resulting award is subject to challenge or is denied enforcement. See CCP art. 786. art. 801 and art. 802, See also infra text accompanying notes 43-46.

32. Daishin'in (Court of Great Judicature), Judgment, Oct. 27, 1928, 7 Minshû 848 (dictum).

33. As adopted by the working group of the UNCITRAL. See art. 28 (3), UN Doc. A/CN. 9/246, 6 March 1984. See also Analytical Commentary at 62, UN Doc. A/CN. 9/264, 25 March 1985.

34. If issues of foreign antitrust law are only incidental to the dispute and involve no important policy concideration, such issues may be found arbitrable by an arbitrator. See, e.g., Mitsubishi Motors Corporation v. Soler Chrysler-Plymouth, Inc., 53 U.S. L.W. 5069 (S. Ct. 1985). 
CCP for setting aside and enforcing awards. Art. 801 provides in essence that an arbitration award may be set aside where (1) the arbitration agreement was not valid, (2) the arbitrator was without jurisdiction, (3) one of the parties was not given reasonable notice and opportunity to be heard, (4) the award was substantially influenced by fraud or other illegal or unjust conduct, or (5) the award is in conflict with law and public policy. ${ }^{35}$ Further, Art. 802 states that the court shall not render an enforcement judgment where there are grounds for setting aside the award. Art. 802, and hence Art. 801, are also applicable to foreign arbitral awards to the extent that those awards are not covered by the 1927 Geneva Convention, ${ }^{36}$ the $1958 \mathrm{New}$ York Convention, ${ }^{37}$ or any bilateral treaties. ${ }^{38}$

\section{Arbitral Institutions}

Although the Japanese law of arbitration provides a very broad framework of what arbitration ought not to be, it gives very few guidelines as to what people can do with respect to arbitration. This deficiency may not obstruct the existing practice of arbitration, since in most cases arbitration is administered by permanent arbitration institutions which have their own arbitration rules. Some of the institutions are of an administrative nature and are set up by an administrative agency and/or a special law which includes a set of arbitration rules. ${ }^{39}$ Among them the only institutions that deal with commercial arbitration are the Central and Prefectural Tribunals for the Settlement of Construction Work Disputes ("TSCWD"). ${ }^{40}$ They were set up by the Law concerning Construction Business" in

35. Provisions of Art. 801 are complicated and redundant. Besides, Art. 801 para. 1 (6) refers to Art. 420, which in turn provides for the grounds for retrial, some of which cannot be applicable to arbitration. 302).

36. Convention on the Execution of Foreign Arbitral Awards, Geneva 26 September, 1927 (92 U.N.T.S.

37. Convention on the Recognition and Enforcement of Foreign Arbitral Awards, New York 10 June, 1958 (330 U.N.T.S. 38).

38. For a list of bilateral treaties, see Doi, supra note 5 at $137-38$.

The applicability of Arts. 801 and 802 to foreign arbitral wards is recognized by courts. See, e.g., Tokyo Dist. Ct., Aug. 20, 1959, 10 Kaminshû̀ 1711; Osaka Dist. Ct., Nov. 27, 1961, 6 Kaiji Hanrei, No.5 at 18. However, this position has not found many supporters among scholars. See generally, Kobayashi, Gaikoku Chûsai Handan no Shônin Shikkô ni tsuite no Ichi Kôsatsu (A Consideration on Recognition and Enforcement of Foreign Arbitral Awards), 468 Hanrel Taimuzu 5 (1982)

39. For example, Kôgai-tô Chôsei Iinkai (Public Nuisance Adjustment Committee) was an administrative committee set up by Law No.52 of 1972 as an external bureau of Sôrifu (Office of Prime Minister).

40. The Central and Prefectural Tribunals for Construction Disputes which will be discussed below, are under the jurisdictions of the Ministry of Construction and each prefectural government, respectively. We will, however, treat them as one for convenience.

41. Law No.100 of 1949. 
order to facilitate the settlement by arbitration, conciliation (chôtei), or mediation (assen) of disputes arising from contracts for construction work. ${ }^{42}$ The other main permanent arbitration institutions that deal with commercial arbitration are the Japan Commercial Arbitration Association (JCAA) and the Japan Shipping Exchange (JSE), both of which are independent, private organizations. ${ }^{43}$ They are well known for their international commercial arbitration rather than purely domestic arbitration. ${ }^{44}$ In sum, the above-mentioned arbitration institutions are the main permanent arbitration institutions that accept commercial arbitration in Japan.

The average number of arbitration awards registered in Japan pcr year in the period of 1953 to 1963 was only $3 .^{45}$ The annual number of arbitration awards went up to 9 in the period of 1964 to 1974 and up again to 20 in the 1975 to 1980 period. Considering the number of awards entered by the TSCWD, the JCAA and the JSE, it is only fair to conclude that most arbitration cases are administered by these institutions. The total number of cases referred to them in 1980 was $77{ }^{46}$ while the number of commercial cases handled by the American Arbitration Association (AAA) in 1970 was $2,658 .^{47}$ In spite o the recent increase, arbitration on the whole has not yet become a popular means of settling commercial disputes in Japan.

A century has brought about little change, so far as purely domestic practice is concerned. The outmodedness of the Japanese law of arbitration may be one of the reasons that people do not utilize arbitration. On the other hand, one explanation for the legislature's failure to revise the law may be that there is not much social demand for arbitration. With the increase in number, variety, and complexity of disputes involving ordinary citizens, dispute settlement mechanisms available at present have turned to be often inadequate to protect citizens' rights. In response to this development, lawyers and scholars have been showing greater interest in arbitration as part of out-of-court dispute settlement machinery. ${ }^{48}$

42. The Law concerning the Construction Business, art. 25.

43. The history and practice of these institutions will be discussed below. See infra text accompanying notes $63-69$.

44. See Taniguchi, supra note 1 at $\mathbf{s} .12 .03$. In this article the term "commercial" is given a wide meaning to cover matters arising from all relationships of a commercial nature. See supra note 8 .

45. Recording of the award with a district court with jurisdiction is required by Art. 791 of the CCP. For statistics, see Table of Statistics on Arbitration prepared by the Office of the Supreme Court, which was reproduced in 54 HôRITSU JiHô, No.8 at 100.

46. See 32 JiYû́ to SEIGI, No.9 at 13-15 (1981); 32 JiYu to SEIGI, No.13 at 95 (1981); JCA Jânaru, Nov. 11,1983 at 29 .

47. See Table of Statistics prepared by the National Institute for Consumer Justice, reproduced in Kojima, Amerika ni okeru Chûsai (Arbitration in the U.S.), 54 Hônrtsu JıHô, No:8 at 36 (1982).

48. See, e.g., Taniguchi; Shôhisha-funsô to Chûsai (Consumer Disputes and Arbitration), Tokushû: Funsô-shori Kikan (Dispute Settlement Machinery), JIYÛ TO SEIGI, Sept, 1981. 
We will now turn to the practice of international commercial arbitration in Japan. As we have seen previously, commercial arbitration represents the largest number of cases recorded in Japan, and most of them are administered by the TSCWD, the JCAA, and the JSE. International commercial arbitration at the JCAA and the JSE is quite well known in the business community. In 1981 the JCAA accepted 5 cases of international arbitration and the JSE accepted 11 cases. ${ }^{49}$ With the exception of the Court of Arbitration of the International Chamber of Commerce, the American Arbitration Association and the London Court of Arbitration, the number of international cases referred to these two institutions seems no fewer than that of their counterparts, for example, in Switzerland or the Netherlands. ${ }^{50}$

From 1975 to 1980 , a total number of 118 arbitration awards were recorded at the District Courts all over Japan, ${ }^{51}$ while in the same period, 11 awards were rendered by the JCAA and 12 by the JSE in international commercial arbitration. ${ }^{52}$ In contrast, only 2 or 3 international cases are litigated every year. ${ }^{53}$ We may conclude from these figures that arbitration is an alternative to litigation for settling international commercial disputes. ${ }^{54}$ In this respect, it is necessary to point out that chotei (conciliation), a semi-formal method of dispute settlement which is available at the JCAA and JSE is rarely called upon by the parties. ${ }^{55}$ This fact is striking to those who know how popular chotei is in the domestic scene. ${ }^{56}$ Two reasons are

49. See 54 Hốritsu JiHô, No.8 at 88 \& 93 (1982).

50. See Cohn Domke, \& Eisenmann, Handbook of Institutional Arbitration in International Trade (1977)

51. See 54 HôrITSU JiHô at 100 (1982).

52. See 54 Hôritsu JiHô at $100 ; 32$ JiYû to Seigi, No.13 at 95 (1981)

53. Most of the international cases are reported in commercial reports such as Hanrei Jiho or Hanrei Taimuzu. In the 1978 to 1984 period only two or three international commercial cases a year came to this author's attention.

54. Note that in international commercial arbitration at the JCAA and the JSE, more than half of the complaining parties are Japanese (almost all of them are corporations). This is not surprising since arbitration was held in Japan.

55. Only one or two cases are annually submitted to the JCAA for conciliation. The JCAA has a board of conciliators and rules for commercial conciliation.

56. In Japan, the paradigm of conciliation is the type which is normally conducted by a conciliation committee (chotei iinkai) appended to courts. The committee is composed of a judge and not less than two conciliatory commissioners (chôtei iin). Therefore one author defines chôtei as "a procedure in which a public organ stands between the parties in order to try to solve a civil dispute by their mutual consent." He then notes that "[t]hus it is to be distinguished from informal conciliation carried out by, for example, a mutual friend of the parties or by a "big figure" in the local community." H.TANAKA, supra note 2 at 492.

Aside from conciliation in family matters, which is conducted at family courts, 156,504 and 1,824 cases were handled in 1984 in small claims and district courts, respectively, while 213,234 and 104,814 suits were handled by those courts in the same year. For more on chotei at a smafl claim or district court which is regulated by the Civil Conciliation Act of 1951 (Minji Chôtei Hô) (Law No.222), see Taniguchi, supra note 1 at s.12.02. 
usually given to explain this difference. One is that foreign parties are not familiar with chotei, and the other is that its mechanism would not function should there be no agreement reached between the parties. ${ }^{57}$

We should not make a hasty judgment from the foregoing discussion that people suddenly become arbitration-minded when they do international business. It is important to remember that one major reason for troubled businessmen to go to the JCAA or the JSE is to get their sôdan (consultation) or assen (informal meditation) services. ${ }^{58}$ In 1980 for example, the JCAA received 826 cases of consultation and 499 cases of assen. ${ }^{59}$ The JSE reports annually 800 cases of inquiries and consultation. ${ }^{60}$ It says that most of the disputes are settled by wakai (compromise and settlement or amicable solution) by means of hanashi-ai (amicable negotiation or talking things over) after going through inquiry of consultation processes. ${ }^{61}$ One JSE expert observes that the tendency to avoid litigation or arbitration is strong in the Japanese national character (kokumin-sei). ${ }^{62}$ The merits of this observation will be analyzed later.

We should also look at the histories of the JCAA and the JSE in order to call attention to some different factors existing between trade group arbitration and ordinary commercial arbitration. The founding of the JCAA was part of a national policy to rehabilitate the Japanese economy by promoting international trade in the wake of World War II. ${ }^{63}$ It was established in 1950 by the Japan Chamber of Commerce and Industry, in response to a proposal of the AAA and in cooperation with major trade and industrial organizations. ${ }^{64} \mathrm{~A}$ significant part of its funds and personnel were provided by the Ministry of International Trade and Industry, since

57. See, e.g., 54 Hônirsu JiHô, No.8 at 87-88 (1982) (a report by a JCAA official). The first reason is based on the assumption that since chotei is informal mediation which has a long history in Japan, foreigners cannot be familiar with such a mechanism. If so this reason seems to be weak in view of the fact that chotei is more similar to mediation which is getting popular support in, for example, the U.S.

58. Assen is a very informal way of mediating between the people involved. In contrast to chotei, there are no rules to be followed in the process. Most typically, a mediator does not call the parties together or he does not even meet them in person. The substance of assen lies in his function as a communication facilitator and/or fact finder between the parties.

59. See 32 JIYÛ TO SEIGI, No.13 at 116 (1981).

60. See 54 Hôritsu JiHô, No.8 at 93. (1982).

61. Hanashi-ai is very often done for its own sake with an expectation that it may help to better the situation, in particular, by creating mutual understanding. It is different from the concept of negotiation in that the latter connotes a purpose to arrive at some specific agreement, while the former tries to create a general atmosphere for a general agreement.

62. See 54 Hôritsu JiHô, No.8 at 98 (1982).

63. See Aoyama, Saiban-gai Funsôshori-kikan no Genjô to Tenbô (Out-of-court Dispute settlement Machinery: Review and Proposal), 32 JiYû To SEIGI, No.13 at 102-106 (1981).

64. See ibid. 
it felt an urgent need to set up an independent organization in order to deal with ever increasing claims and complaints from foreign customers, many of whom were American businessmen. ${ }^{65}$

The JSE arbitration not only had quite a different start but was to experience a different fate from that of the JCAA. The JSE established its arbitration department in response to the need of maritime merchants. The moving force must have been the same as for other trade groups which would want to have their own self-regulation machinery. The decision of the JSE to set up its arbitration department in 1929, many years after its establishment, and its subsequent success were largely related to the effort to promote its own standard forms of contract with an arbitration clause. ${ }^{66}$ The increase in arbitration went hand in hand with the spread of many JSE forms. Prestige of JSE arbitration helped it to survive the Trade Association Act of $1948^{67}$ which prohibited a trade association from arbitrating a dispute between its members and/or nonmembers. ${ }^{68}$ The long-standing JSE arbitration practice was saved from the general prohibition of the Act by a special law entitled the Law Concerning Maritime Arbitration. ${ }^{69}$

With minimum control by the law, arbitration at these institutions proceeds in accordance with their respective rules of procedure. Furthermore the JCAA and the JSE have been active in promoting international cooperation with other institutions in order to facilitate arbitration. For example, the JCAA has signed cooperation agreements with 23 institutions as of $1981 .^{70}$ As for the JSE, it has a long practice of mutually recognizing and adopting other institutions' forms of contract. $^{71}$ In addition, in 1982 it concluded a cooperation agreement with the Asian African Law Consultative Committee (AALCC) and the Kuala Lumpur Regional Arbitration Centre (KLRAC). As a result of the 1982 agreement, maritime arbitration cases referred to the KLRAC are to be administered by the JSE, including appointment of arbitrators in the absence of the parties' choice. ${ }^{72}$

The lack of interaction between the law of arbitration and practice seems to be getting wider as arbitration at the JCAA and the JSE are keeping track with international development. Since rules and practice of arbitration institutions are

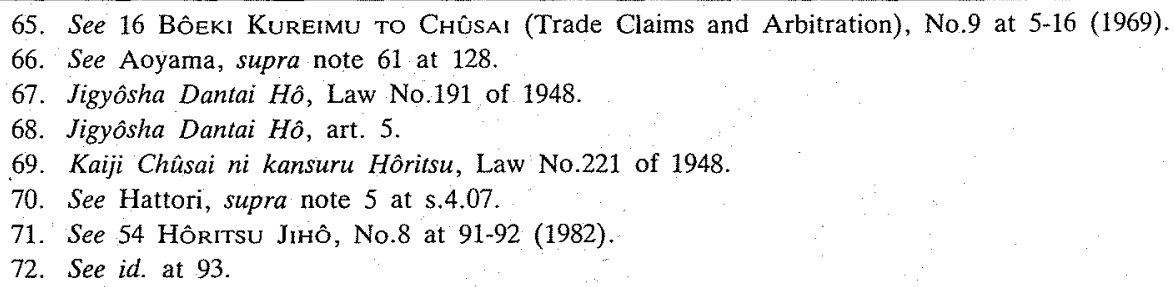


moving at an increasing speed toward unification, Book VIII of the CCP will greatly decrease in importance in the Japanese practice of international arbitration.

The increase in number and experience of arbitrations at these institutions is one of the forces which supports a new legislation. Another moving force is the increasing interest by scholars and practitioners in the law and practice of arbitration. Their proposals for legislative action are mainly a response to the development of international arbitration.

\section{Arbitration and Soclal Practices of Dispute SetTlement}

If one can observe that the tendency to avoid litigation or arbitration is strong in the Japanese character, there must be some explanation for it. One of the widely held views is that the Japanese try to avoid any adversarial method to settle a dispute because they hate conflicts and love harmony $(w a) .{ }^{73}$ This love of $w a$ (is this again their kokumin-sei or national character?) may be explained as a product of social homogeneity, ${ }^{74}$ or it may be traced back to the prototype of the Japanese as an agrarian nation. ${ }^{75}$ All these factors would contribute to keeping the number of disputes down and consequently keeping the number of litigations or arbitrations down. They may also explain why people act in a certain way when a dispute arises. But what we need here is a more functional and pragmatic approach, without analyzing a maze of causation and correlation of these factors. We will proceed by attempting to answer the two questions: Why do people choose or not choose arbitration to resolve their dispute? Are there alternatives to arbitration?

As we have seen, deficiencies of the law of arbitration keep people from utilizing arbitration and work against their choosing ad hoc arbitration which is not administered by an arbitration institution. Secondly, distrust of a private decider must be an important factor in ordinary people's reluctance to utilize arbitration. ${ }^{76}$ Usually people have more confidence in public courts. ${ }^{77}$ The distrust of private

73. Interestingly enough, this kind of view is also expressed by a foreign resident doing business in Japan as a lawyer. See Gaikoku-jin kara mita Nippon no Hôritsu to Jitsumu (Japanese Law and Practice in the Eyes of Foreigners). 781 JuRIsuro 132, (1983).

74. See Mikazuki, Tetsuzuki-hô teki ni mita Kokusai Chûsai no Mondaiten (Some Problems of International Arbitration: Procedural Aspects), JCA JÂNARU, May 1980 at 11-13.

75. See ibid.

76. Once a proposal to introduce arbitration in the Law concerning Construction Business was strongly opposed by contractors for this reason. See Chûsai-nin wa Kataru (Arbitrators Talk), JCA JÂNARU, Jan, 1979 at 9. See also Taniguchi, supra note 1 at s.12.03.

77. See supra note 76, JCA JÂNARU at 10 . 
deciders cannot explain why people would go to an arbitrator rather than to a judge for an international case. A third factor is related to the above two factors. That is to say, the existence of authoritative arbitration institutions can explain the relative popularity of international arbitration. These institutions can administer arbitration for the parties in whole or in part, thus reducing the trouble of making an agreement or appointing the arbitrator(s). Fourthly, it should be pointed out that little knowledge of arbitration on the part of people is a factor to explain the reluctance to use arbitration. ${ }^{78}$ This factor is related to all the other three factors.

The various factors expressed by the catch-all concept of kokumin-sei and the abovementioned four factors will certainly influence, to different degrees, a decision of a party to a dispute to choose a method to resolve the dispute. The decision is made by taking into consideration both his perceptions and the other party's possible reactions to these factors. Cost and speed are also important considerations. This is more usual with a business dispute than with a dispute in private life. Businessmen will choose the method which works best in a certain situation, while a private citizen may choose a less effective way of dispute settlement over a more effective one, because he likes it better. In an everyday life situation one may prefer the method which is less confrontational to the other party even though it is less effective. ${ }^{79}$.

This kind of consideration is no doubt found very frequently among may Japanese, but that is not to say that such consideration is limited to them. Therefore we must look for an index which would show a difference between domestic and international practices of Japanese businessmen and also explain the behavior of people in business and private life.

It is generally accepted that dispute settlement in Japan is very informal. ${ }^{80}$ This proposition seems to be supported by two observations. One is that there is some other recourse than a formal mechanism to dispute settlement. The other is that informal mechanisms are functioning very effectively. The connecting factor of the two observations is hanashi-ai (amicable negotiation or talking things over).

78. See Taniguchi, supra note 1 at $\mathbf{s . 1 2 . 0 3 .}$

79. See JuRisto, supra note 73 at 143 .

80. See Taniguchi, supra note 1 at s.12.01. A dispute settlement can be "informal" at three levels, first, how it is created, second how it proceeds, and third how a substantive issue of a dispute is decided. Hense it would be more precise, in this case, to refer to the creation level as "private" or "voluntary," the procedural level as "informal," the substantive criteria as "delegal." "Delegal" criteria do not necessarily exclude "legal" rules. This analysis applies to chôtei. Chôtei by a private individual mediator is private-informal-delegal, chôtei at the JCAA, for example, can be semi-official-semi-formal-delegal, and chotei in court is official-semi-formaldelegal. 
Hanashi-ai can be translated to English as "friendly discussion or consultation" but it has functionally and often symbolically a more distinctive place in dispute resolution. It is functionally similar to negotiation which can literally be translated to "kôshô." Hanashi-ai, however, lacks the purposiveness of negotiation or kôshô to reach some kind of decision or agreement. The core notion of hanashi-ai is to sit down, as it were, and talk things over in a friendly manner. In addition the word connotes people's expectation of improving the dispute situation by generating mutual understanding ${ }^{81}$ People also expect from the hanashi-ai process access to a general friendly atmosphere which would facilitate generating some agreement. They will regard a round of hanashi-ai as success if it at least generates mutual trust or friendship among the participants, because that is likely to preserve their relationship so as to try another round of hanashi-ai. In a sense people want to believe and want others to believe that hanashi-ai should work.

Another aspect of hanashi-ai is that there is often some symbolism in proposing it. The party by offering to enter hanashi-ai before going to a third party ("outsider") to intervene shows its willingness and good faith to settle the matter amicably, quite apart from its expectation as to the effectiveness of that hanashi-ai. Therefore rejecting that offer would be taken not only as lack of good manners but also as rejection of a bona fide effort to resolve the dispute. In effect it is the paradigm of dispute settlement in Japan and also a social norm which forms and regulates people's practice. What is more important is its function as the model or ideal type of dispute settlement rather than its effectiveness. Not only private citizens but corporations conform their behavior to hanashi-ai. They act believing or expecting that it will work. Since it is the norm, one is expected to pay respect or at least lip service to it.

In a survey conducted by the JCAA, 51 per cent of the total of 669 companies replied that the most desirable way to settle a commercial dispute is by wakai achieved by hanashi-ai. ${ }^{82}$ Forty-eight per cent stated that they would choose from among wakai, litigation, chotei, and arbitration, depending upon the nature and amount of the claim. According to another survey, conducted by a legal periodical, more than $75 \%$ of 40 responding companies indicate hanashi-ai as the most

81. It is interesting to note that the Japanese often identify mutual understanding with mutual agreement. Take, for example, the phrase "hanaseba wakaru" (we will thaw if we talk). The underlying belief behind this phrase is that we are all created equally as hito (humans) and that we ought to know others and be known in turn. This tendency may be derived from the fact that many communities in Japan are ethnically homogeneous where there are few true conflicts which must only be dealt with by agreening to disagree.

82. See 19 JCA JÂNARU, No.9 at 28 (1972). 
common method of dispute resolution. ${ }^{83}$ Next to hanashi-ai are litigation and settlement in court during litigation (soshô-jô no wakai). Other methods such as waiver (kenri hôki), conciliation (chôtei) or arbitration are not very common. The former survey is noteworthy because it seems to support the existence of the hanashi-ai norm among Japanese businessmen, while the latter must be noted as it evidences the unpopularity of chotei and arbitration in the business world. ${ }^{84}$ More significant is the clear indication in the JCAA survey that Japanese corporations choose a suitable method of dispute resolution on the basis of calculation rather than favor one way invariably as a result of its inherent nature. ${ }^{85}$

In a dispute between Japanese parties, it is most probable that hanashi-ai will reach some amicable solution. And since hanashi-ai is the norm for dispute settlement in Japan, it is not unreasonable for a Japanese businessman to try the model method first. If it fails, he would simply look to other methods which may be available. There is more business judgment involved here than wa or kokumin-sei. Where a consultation or negotiation process fails to function, resort to arbitration becomes a reasonable choice for Japanese businessmen. Frequent use of the arbitration clause in international contracts by Japanese companies can be explained by some common reasons for arbitration: speed, lower cost, expertise and greater privacy. There are other reasons why arbitration is more often relied upon by people engaged in international business. Parties' freedom to choose the rules of procedure and the rules applied to the substance of a dispute have more significance in an international arena. Arbitration is likely to be chosen where there is reason to believe that litigation in a particular country may produce some unfavorable or even unfair results. ${ }^{86}$ In a contract negotiation, the difficulty of reaching an agreement on a choice of forum or even a choice of law may lead the parties to arbitration. This factor is even more controlling when a party to an

83. See Kaisha Hômu no Genjô to Kadai - Dai 4ji Jittai Chôsa no Bunseki Hôkoku (Legal Department System and Problems - Report and Analysis of the Fourth Survey) NBL Special Issue No.8 at 110-48.

84. For typical chôtei, see supra note 56. For other examples, see supra note 80.

85. In this regard, it must be noted that individual Japanese may not be so subjective or emotional in "avoiding" litigation, as they often believe them to be. According to a survey conducted in and around Osaka by Professor Yoshio Sasaki, out of the total of 2,184 responses, 1,065 listed various objective reasons not to go to court. See M.ÔKI, NiHONJIN No HÔKAN'NEN - SeIYo HôkAn'NEn tono Hikaku (Japanese Notions of Law Comparison with Western Counterparts) 241-42 (1983).

86. One staff member of a legal department at a large trading company points out that the reason for arbitration in the U.S. for his company is to avoid a jury trial, which is not favorable to Japanese. See Kokusai Shôji Chûsai Seido nitsuite Jitsumuka wa Kataru (Symposium: Practitioners' View toward International Arbitration), JCA JÂNARU, Jan., 1980 at 8. See also Miyazawa, Organizational Adaptation to Multiple Environments: Legal Departments of U.S. Subsidiaries of Japanese Corporations, unpublished Ph. D. dissertation, Yale University, 1985. 
agreement is a state. On the other hand, litigation may be preferred where the country to which the other party belongs is not hospitable to arbitration and/or foreign arbitral awards. ${ }^{87}$ We are thus not surprised to see that the practice of Japanese businessmen in international cases may deviate from their domestic practice. They are more likely with good reason to turn to arbitration in a international case than in a purely domestic case.

To put it in a broader perspective, what is at the root of this difference in practice is the Japanese businessmen's awareness that they should apply rules of behavior which often deviate from their social norms. Therefore, they learn, often the hard way, that their belief and expectations toward hanashi-ai are not always shared in the international business world. It is true that any businessman should learn to make a few adaptations to deal with a dispute situation arising from international business. But if he is from a country which has a Western-type of legal system that has more or less incorporated Western social norms about dispute settlement, he is still safe on a spectrum between his national and international norms. A Japanese businessman in an international arena must face a serious discontinuity of social norms, and he has to accommodate if he wants to make a deal. ${ }^{88}$ Thus, he has not come a long way from his 19 th century countrymen who adopted Western law in order to get "fair and equal" treatment by the developed countries.

\section{Conclusion}

By its overall reception of Western law in the 19th century, Japanese society experienced a sea change. Many institutions which were newly introduced by codification have now developed their own practice, and the correlation between law and practice is significant. Yet arbitration is one of the few areas where the gap between law and practice is still unfilled, ${ }^{89}$ although there is change in the sense that there was no practice of arbitration a hundred years ago while there is some being developed now. In sum, arbitration has not taken root in Japanese soil as a dispute resolution mechanism.

87. See Symposium, supra note 85 at 5 . In terms of enforcement of the decision, however, enforcement of a foreign judgment may turn out to be more troublesome than that of a foreign arbitral award. In the former case, there is no international convention comparable to the 1958 New York convention for foreign arbitral awards.

88. See Mikazuki, supra note 74 at 13 .

89. One striking example of "the law on the books" is the Jury Act (Baishin Hô), Law No.50 of 1923. The Act provides for a jury trial for a criminal case, though there is no jury system existing in Japan. This fact is also explained by people's distrust in private deciders and their trust in judges and the judicial system in general. 
The unpopularity of arbitration in purely domestic settings is partly explained by the fact the hanashi-ai is the norm of dispute settlement. This fact may also explain why litigation is little used..$^{90}$ If litigation is the model of an official-formallegal type of dispute resolution, hanashi-ai is the model of a private-informaldelegal method. ${ }^{91}$ If we place litigation in the center of dispute processing, other methods such as arbitration, mediation or negotiation may be characterized as an alternative to litigation; that is, the latter, being an informal way, is seen as supplementary to litigation. In contrast, when one can see hanashi-ai as a model of dispute settlement mechanism, mediation, arbitration or litigation can be characterized as more formal and seen as an alternative to hanashi-ai. ${ }^{92}$ In either account arbitration has yet to become an alternative dispute resolution method in purely domestic cases. In a commercial context, litigation and settlement in court during litigation can in fact be better alternatives to hanashi-ai. ${ }^{93}$ In a setting where hanashi-ai is less effective, they will seek recourse to other means of dispute settlement. In this case, too, people tend to choose an informal method so that their norm of wakai-through-hanashi-ai (settlement through amicable negotiations) may best be preserved.

In an international context, where commercial people often find their familiar informal way unworkable, they must choose arbitration or litigation. Here arbitration can be a better alternative to both litigation and hanashi-ai. Companies insert an arbitration clause when they think arbitration to be more effective in a given situation than alternative methods. They often learn to deviate from their domestic practice of dispute settlement in favor of international practice, which is greatly influenced by Western, especially Anglo-American, standards. In this respect arbitration can be seen as a compromise on the part of Japanese businessmen. It would however be interesting to suggest that arbitration may also be a compromise by Western, typically American businessmen, who tend to see litigation as the model of dispute resolution.

90. It must be noted that litigation has become an important means for the socially weak to enforce their rights against industry and the government. This may indicate that between the parties with totally different bargaining power, there is not much chance that hanashi-ai will work.

91. For the meaning of "private-informal-delegal," see supra note 80 .

92. The former characterization seems to be used as a frame of reference in the U.S. See, e.g., Sander, Varieties of Dispute Processing, 70 F.R.D.79 (1976). The same frame of reference is also used by some Japanese scholars as a working model to analyse the Japanese system of dispute processing. But does it work in Japan? Is it a sufficient tool of analysis? It seems more plausible to say that the latter approach is necessary in order to place the Japanese system in a proper perspective which enables us to make an international comparison.

93. See supra text accompanying note 83 . 
The use of arbitration has been promoted by the existence of arbitration rules developed by such institutions as the JCAA or the JSA which have arbitral bodies. Their rules incorporate and supplement the outmoded law of arbitration. Their readiness and effort to further international cooperation with their counterparts abroad and their promotion of standard arbitration clauses or standard contract forms with arbitration clauses are important factors which encourage and assist arbitration. On the other hand the absence of authoritative institutions with good resources of arbitrators, coupled with lack of guidance and assistance of arbitration law, would discourage the use of arbitration.

An increasing number of proposals and demands for new legislative action are coming from scholars as well as practitioners who have observed and studied the recent development in law and practice of international commercial arbitration. On the other hand, the domestic development in this field is slow, and arguments for revisions of the $\mathrm{CCP}$ are presented by the proponents of extra-judicial dispute settlement mechanisms in order to meet the increase of new types of disputes. ${ }^{94}$

Any legislative reform of the Japanese law of arbitration must incorporate various factors concerning social norms, social needs, and practice concerning arbitration. Since we have observed different factors between domestic and international contexts, it seems more reasonable to adopt two different approaches, each intended for its respective context. As a practical matter, Book VIII of the CCP should be revised to serve domestic purposes, and a new legal regime should be worked out to assist the use and practice of international commercial arbitration. Only in this way will Japan gradually be able to achieve harmony between the law and social practice concerning arbitration, the goal which had to be sacrificed a century ago to the overriding purpose of modernization.

94. See supra text accompanying note 48 . 